\title{
sciendo
}

10.2478/jlecol-2021-0019

Journal of Landscape Ecology (2021), Vol: 14 / No. 3.

\section{LANDSCAPE PAINTING IN THE RESEARCH OF LANDSCAPE CHANGES}

\author{
HANA SKOKANOVÁ ${ }^{1 *}$, TOMÁŠ SLACH ${ }^{1}$, MAREK HAVLíČEK $^{1}$, PETR HALAS $^{2}$, \\ JAN DIVÍŠEK ${ }^{2}$, ZUZANA ŠPINLEROVÁ ${ }^{3}$, TOMÁŠ KOUTECKÝ ${ }^{3}$, JAN ŠEBESTA $^{3}$, \\ EVA KALLABOVÁ ${ }^{2}$
}

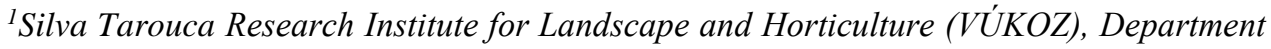
of Landscape Ecology, Lidická 25/27, 60200 Brno, Czech Republic

${ }^{2}$ Institute of Geonics, Department of Environmental Geography, The Czech Academy of Sciences, Drobného 28, 60200 Brno, Czech Republic

${ }^{3}$ Mendel University in Brno, Department of Forest Botany, Dendrology and Geobiocoenology, Zemědělská 3, 61300 Brno, Czech Republic

* Corresponding author e-mail: hana.skokanova@vukoz.cz
\end{abstract}

Received: $1^{\text {st }}$ November 2021, Accepted: $14^{\text {th }}$ December 2021

\begin{abstract}
The article analyses possibilities of using landscape paintings in the studies of land cover changes. It examines 112 paintings from 1728 till 1976 and compares them with existing topographic maps. It compares land cover depicted in the paintings with present landscape and it studies changes of landscape derived from topographic maps from several periods, ranging from 1764 till 2006. In order to make the analyses, all paintings had to be localised as precisely as possible. This was done with the help of present map and by field work. Field work was also necessary for identifying main land use/cover changes in comparison to landscape painting. A TopoLandUse database, consisting of land use vector data from five periods, based on vectorisation of topographical maps, was used for analysing land use/land cover changes, their rates and main trends.

Comparison of landscape paintings with topographic maps showed overall agreement between both types of sources. Paintings often capture details that cannot be found in the maps, thus enriching gained data. They can also serve as a source for periods from which no maps and other cartographic sources exist. However, paintings are as reliable as the painter makes them.

Comparison of landscape in the paintings with the present landscape showed general extensification and abandonment of the landscape, which manifested mainly in the increase of woody vegetation and decrease of arable land. Analyses of land cover changes in the surrounding cadastres in several periods confirmed general trends that can be seen in not only the Czech Republic but also elsewhere in Europe. These are mainly spread of both woody vegetation and permanent grassland at the detriment of arable land but also increase in built-up and recreational area in the settlements.
\end{abstract}

Keywords: landscape painting, land cover change, Czech Republic 


\section{INTRODUCTION}

Landscape changes, including changes in land use/land cover have an increasing impact on biodiversity (Zebisch et al., 2004; Jung et al., 2020) and contribute to the ongoing climate change (Rounsevell \& Reay, 2009) as well other environmental changes (Guse et al., 2015; $\mathrm{Hu}$ et al., 2020). The study of landscape changes has experienced rapid progress in the past 30-40 years and shifted from a simple description of land cover changes (e.g. Kienast, 1993; Skanes \& Bunce, 1997) through examining their driving forces (Lieskovský et al., 2013; Skokanova et al., 2016) to simulating future land cover development (Popovici et al., 2018). All these efforts aim at improving landscape planning and mitigating consequences of human activities such as rapid urbanisation (Bao et al., 2019), biodiversity loss (Yang et al., 2017) or land degradation (Liu et al., 2011).

Many data sources can be used for analyses of cover changes. The most common are historical maps in various scales (Bender et al., 2005; Havlicek et al., 2018a), aerial photographs (Hirst et al., 2000; Skokanova et al., 2020), satellite images (Barasa et al., 2010; Fonji \& Taff, 2014) and statistical, mainly census or cadastral data (Allanson \& Moxey, 1996; Petek, 2002). Less frequent sources are represented by photographs (de Muelenaere et al., 2012; Tracewski et al., 2017) and landscape paintings. However, both sources have been somewhat neglected to date, although they represent a valuable source of data for studying landscape change (Lacina \& Halas, 2015). Landscape paintings as a source for analysing landscapes were recognised already in the 1970s (Rees, 1973). Since then, scattered mentions of their use from different world regions can be found in the literature. For example, there is a group of resources targeting portraying of Australian river landscapes with subsequent assessment of their development (Brown et al., 2002; Gaynor and McLean, 2008; Boon, 2017), examining landscape changes in the Himalayas (Devrani \& Singh, 2012) or using topographical art for rediscovering lost landscapes in Italy (Piana et al., 2021).

Realistic landscape painting entered fine art in the mid-19 $19^{\text {th }}$ century and this approach increasingly replaced traditional Romantic school. The concept of the romantic school was based on artificially composed landscape motifs and figural staff, mostly painted in the studio by heart with an emphasis on mood and impression. On the contrary, the realistic painters created in nature and open air and the emphasis was put on objectivity and neutrality (Landin, 2020). They could observe and register and record their authentic experience and impressions (so-called Barbizon school of art) (Fraser, 2017). The precision of paintings depended on the individual access, style and inner motivation of authors; however, they probably highlighted a specific landscape composition, aspects, and interesting details. Besides, the realistic painters, who denied the romantic concept, expressed the social aspect of that time in the landscape. Thus, we can recognize the daily life in the majority of studied panoramas. Landscape paintings can be either seen as a supplementary source of spatial data recorded beyond other sources, such as maps, or as a primary data source for areas or periods with no other similar data available. For example, there are gaps between individual available historical map sources, such as military surveys of the Habsburg Empire (Konkoly-Gyuró et al., 2017) for Central Europe in the 18th and 19th centuries. However, these gaps can be at least partially filled by available paintings providing graphical information complementing existing written data (such as chronicles, yearbooks etc.).

A crucial precondition of using landscape paintings in land cover analyses is that their precise localisation and the time of their origin are known. So far, only a few studies have highlighted this precondition (Lacina \& Halas, 2015; Frajer \& Simacek, 2019). Another important issue is the reliability of depicting the real landscape at the time of the painting's origin. Visual arts such as landscape painting were often utilised to express the relationship between humans and nature or determine perception and understanding of the environment 
Skokanová H., Slach T., Havlíček M., Halas P., Divíšek J., Špinlerová Z., Koutecký T., Šebesta J., Kallabová E.: Landscape painting in the research of landscape changes

(Frajer \& Simacek, 2019). Some artworks are very realistic and capture a lot of interesting details and information. In contrast, others are less real or even invented, leading to misleading conclusions about the landscape composition. Therefore, not every landscape painter with his/her work is suitable for such purposes and careful selection of appropriate artworks is needed.

The aims of this paper are as follows: 1) can comparison of landscape depicted on a painting with a topographic map lead to the estimation of painting's accuracy of the given landscape? 2) How has the landscape depicted in the painting changed over time? 3) What main changes occurred in the locality surrounding painter's stand and his perceived landscape?

\section{MATERIAL AND METHODS}

To answer research questions, 112 landscape paintings from Moravia and eastern Bohemia capturing the period from the mid $-18^{\text {th }}$ century to 1970 s were selected and analysed. The selection process followed these criteria: 1) the depiction of the landscape had to be realistic, i.e. it was possible to clearly distinguish at least basic land cover types; 2 ) the painting had to show a landscape from a wider perspective, i.e. paintings with details only (e.g. a tree, a church, etc.) were omitted; and 3) a year or at least a period of the painting had to be known. Especially the last two criteria were revealed to be the most constricting. Indeed, many paintings capture a realistic image of the wider landscape, however, not so many can be easily dated. This applies especially to paintings from earlier periods. Paintings were grouped into three groups according to their origin time - paintings painted in the period 1728-1850 (group A), paintings painted in the period 1864-1930 (group B) and paintings painted in the period 1931-1976 (group C) (Fig. 1). The groups respect availability of the map sources. Three basic indicators regarding relief were calculated based on digital model relief: minimum, maximum and mean elevation. These characteristics helped in interpretation of land cover changes and comparisons with general trends characteristic for different elevations.

Each painting had to be localized as accurately as possible. This was done with the help of the current topographic map and field survey. The geographical information in name of the painting was mostly used to determine the location of the original painting and comparative photography. We profited from old and new map sources and documentation. Moreover, interviewing local people, especially older witnesses, was very beneficial. For a better view, we preferred to take comparative photographs in wintertime. The field survey also helped to identify the direction of the painter's view (Lacina \& Halas, 2015; Havlíček et al., 2021).

To assess the accuracy of each painting, available topographic maps from various periods, which were closest to the painting's date, were used. These maps included 1st Austrian military survey (scale 1:28 800) from 1764-1768, Franziscean stable cadastre (scale 1:2 880) from 1826-1840, 2nd Austrian military survey (scale 1:28 800) from 1836-1852, 3rd Austrian military survey (scale 1:25 000) from 1876, revised 3rd Austrian military survey (scale 1:75 000) from 1912-1938, Mestischblatter (scale 1:25 000) from 1943-1944, Definitive military survey (scale 1:20 000) from 1948, Czechoslovak military topographic maps (scale 1:25 000) from 1953-1956, Czechoslovak military topographic maps (scale 1:10 000) from 1956-1962 and Czechoslovak military topographic maps (scale 1:25 000) from 1986. Each painting was then visually compared with a corresponding map, and notes concerning accuracy were recorded. 
Fig. 1: Localisation and direction of researched landscape paintings, divided into three groups according to their date of origin

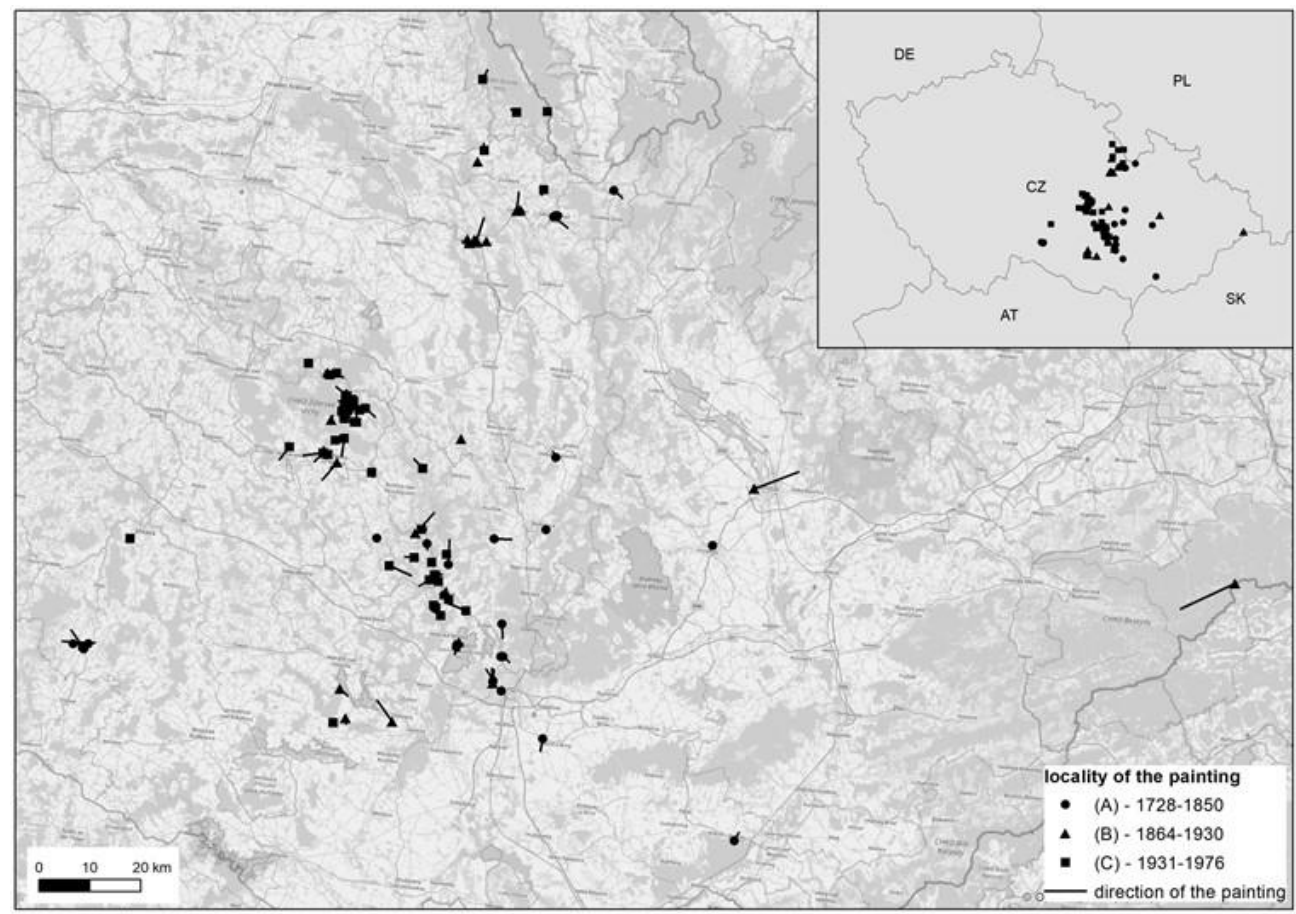

To assess land cover change, the landscape painting was compared with the present situation (years 2019-2021) recorded during the field survey. Evaluation of the paintings was based on a detailed assessment of responsible members of the team who independently quantified the land cover changes for every single painting. The original painting was visually compared with the current scene picture captured by a camera and fitted to the same frame size and scale as the original. An example can be seen in Figure 2 and Figure 3. Due to the subjectivity of visual assessment, we set simple criteria for evaluation (Table 1). Based on the criteria, certain habitats and land cover categories were evaluated: arable land, permanent grassland, woody vegetation, built-up areas, and water bodies. Since it is difficult to accurately capture the exact extent of the land cover type depicted on the painting, quantification of the land cover changes had to be done by approximation rating. The rating scale is indicated in Table 1. Comparison of a painting, present situation and respective topographic maps can be seen in Figure 2 and 3. 
Skokanová H., Slach T., Havlíček M., Halas P., Divíšek J., Špinlerová Z., Koutecký T., Šebesta J., Kallabová E.: Landscape painting in the research of landscape changes

Table 1: Rating scale of land cover changes captured in a landscape painting and present landscape

\begin{tabular}{ll}
\hline scale & description \\
\hline++ & very high increase in the area of the respective land cover category \\
\hline+ & high increase in the area of the respective land cover category \\
\hline 0 & the area of the respective land cover category has not changed (a change in the \\
& localisation could occur, but the total area remained more or less the same)
\end{tabular}

- $\quad$ high decrease in the area of the given land cover category

N/A the land cover category has not been found in the painting

Fig. 2: Original painting (left) Louka pod Boračí (Meadow below Borač; Josef Jambor, 1957, oil on canvas, 50 x $54.5 \mathrm{~cm}$, source: private collection, reproduction provided by Slovácko Gallery) and the present landscape (right; photo Petr Halas)
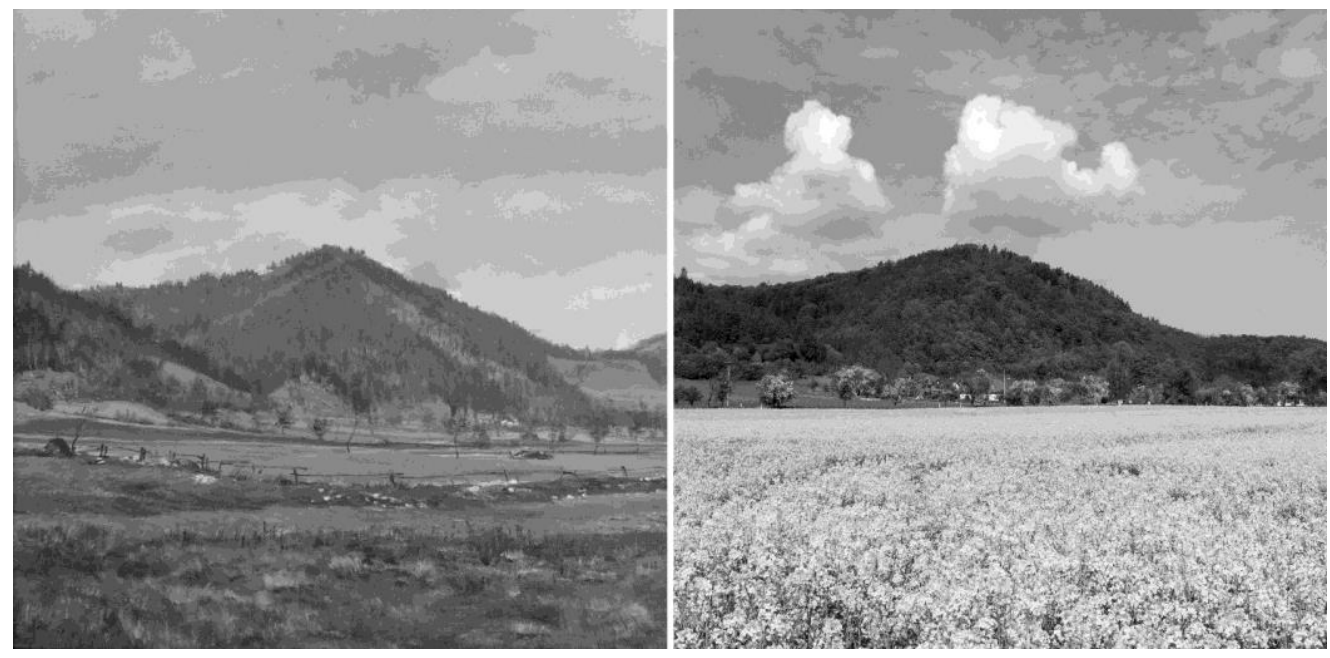

Finally, we used the "TopoLandUse" database to assess land cover changes and their trends. This database includes five land use vector layers from 1840s, 1870s, 1950s, 1990s and 2000s, which were created by vectorising old topographical maps at middle scale from respective periods. The land cover is distinguished in nine categories - arable land, permanent grassland, orchard, vineyard, forest, water body, built-up areas, recreational areas and other areas (Skokanova et al., 2012). Analyses were done for cadastres, where paintings were localised and for cadastres in the direction of the painting's view. Besides the development of land cover categories, the rate of change (transformed to a 10-year rate) and main land cover flows were analysed. These analyses were based on the overlay of basic land 
cover layers. The different number of land cover layers was used for different group: five for group (A), four for group (B) and three for group (C).

Fig. 3: Topographic maps showing the landscape of the painting Louka pod Boračí and the painter's view in the period of its acquisition, used for assessing accuracy of the painting (left), and present situation (right)

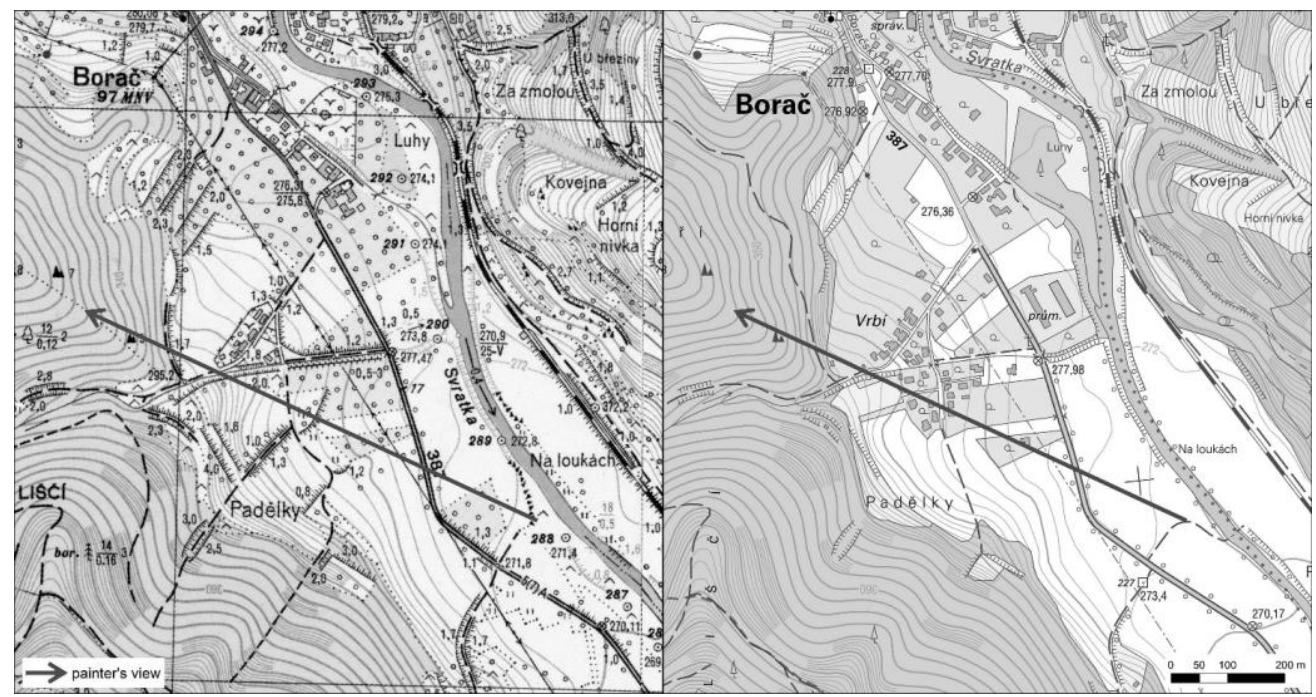

\section{RESULTS}

Out of 112 selected paintings, 40 were created in the second half of the $20^{\text {th }}$ century, 35 in the first half of the $20^{\text {th }}$ century, 22 in the first half of the $19^{\text {th }}$ century, 11 in the second half of the $19^{\text {th }}$ century and four in the $18^{\text {th }}$ century. Group (A), i.e. paintings created in the period 1728-1850, has 26 paintings, in group (B) - paintings from period 1864-1930, there are 25 paintings, and group (C), i.e. painting from period 1931-1976, is the most numerous as it contains 61 paintings. The minimum, maximum and mean elevation for each group is shown in Table 2.

Table 2: Minimum, maximum and mean elevation (m ASL) for three groups of paintings

\begin{tabular}{lccc}
\hline Group & minimum elevation & maximum elevation & mean elevation \\
\hline (A) & 185 & 558 & 363 \\
\hline (B) & 215 & 897 & 411 \\
\hline (C) & 247 & 779 & 576 \\
\hline
\end{tabular}




\section{Comparison of paintings with maps from the corresponding period}

Visual comparison of the paintings with topographic and cadastral maps showed relatively high agreement with modern maps from the second half of the $20^{\text {th }}$ century (represented by Czechoslovak topographic maps; $75 \%$ of the total number of respective group) but to some extent also with old topographic maps from the $18^{\text {th }}$ and $19^{\text {th }}$ centuries (represented by either stable cadastre maps or maps from Austrian military survey; $88 \%$ of the total number of respective group). Missing major features, like water bodies, grassland or larger woodlots, were noted only for five paintings. These missing features were surprising because the compared maps were either from the year of the painting or from a close period.

Comparison of the paintings from the first half of the $20^{\text {th }}$ century was a bit problematic. This was due to scarcity of more detailed topographic maps (large to medium scale 1:10 000 to $1: 25000$ ), which were accountable only for $48 \%$ of the total number of respective group. Therefore, more than half of the compared maps lacked some land cover categories (often represented by grasslands) depicted on respective landscape paintings. Small features, like solitary trees, alleys or very small patches of grassland, depicted on the paintings, were usually not captured by the maps regardless of the scale.

\section{Land cover development}

Comparison of land cover depicted in the landscape paintings with present situation showed several trends. Regardless painting's date, the landscape has been significantly overgrown by woody vegetation but has been also affected by the spread of built-up areas (Figure 4 and 5).

Fig. 4: Example of one of the original paintings used for the analysis (Fedor Antonín Kracík, Svratka v zimě [Town of Svratka in the winter], 1926, tempera on canvas, $70 \mathrm{x}$ $100 \mathrm{~cm}$, source: Town museum and gallery in Svratka)

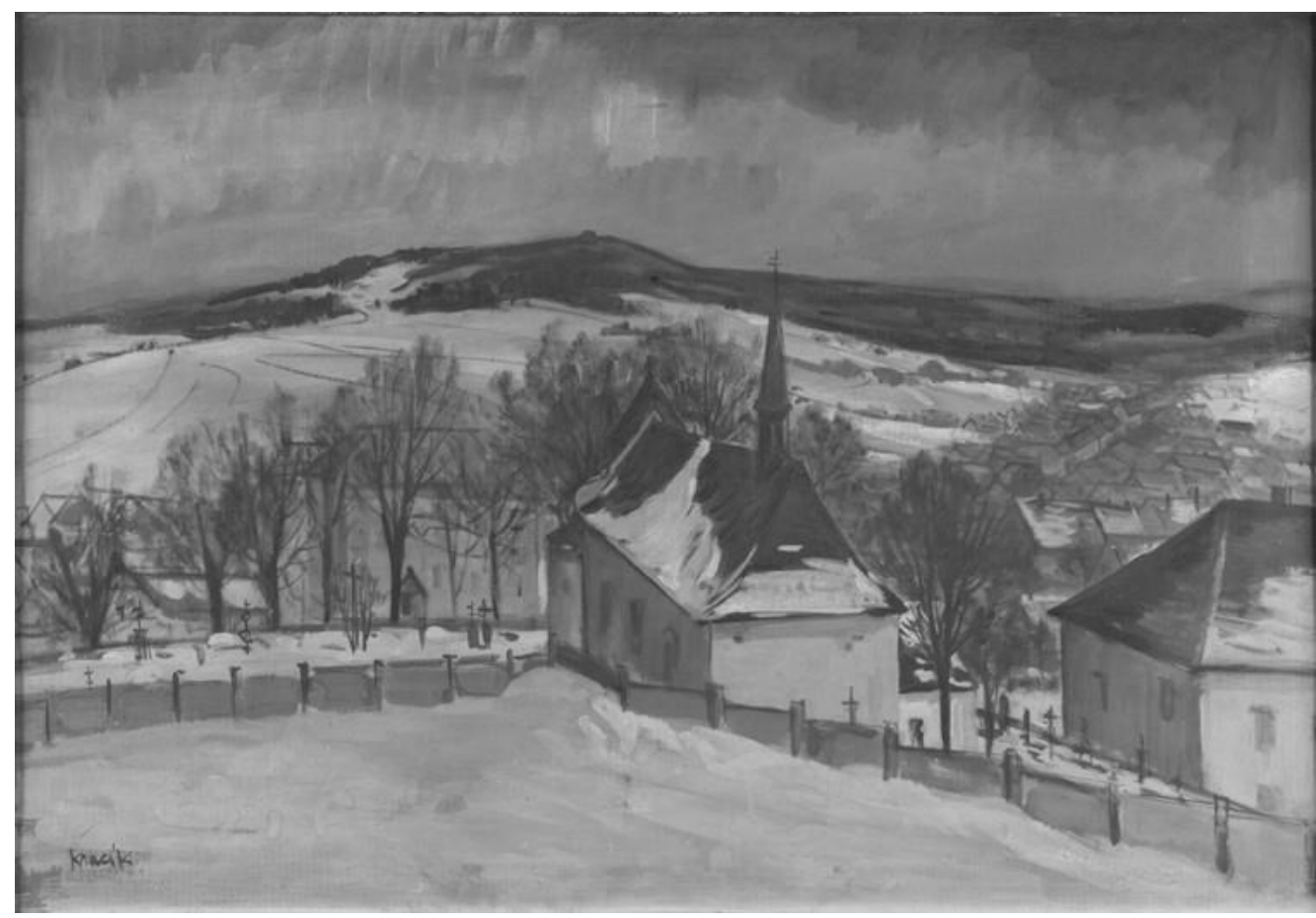


A very high increase in the area of woody vegetation was noted for $4 \%$ of the paintings, while a high increase concerned $88 \%$ of the paintings. The increase was typical for paintings from group (C). Only $8 \%$ of the paintings were not affected by the increase in woody vegetation (Table 3). Regarding the built-up areas, a very high increase was noted for $7 \%$ of the paintings and a high increase for $41 \%$. This increase occurred in all groups of paintings. Nearly one third of the paintings did not experience any increase in the built-up areas, typically from group (C), and the decrease was noted for $4 \%$ of the paintings. It should be stressed, that $15 \%$ of the analysed paintings, mainly from group (C) did not have any built-up area (Table 3).

Fig. 5: Current state of the 95 years old Kracík's view, increase $(+)$ in categories of woody vegetation and built up area in parallel with decrease (-) in categories of arable land and grasslands were observed in this case (photo: Tomáš Slach)

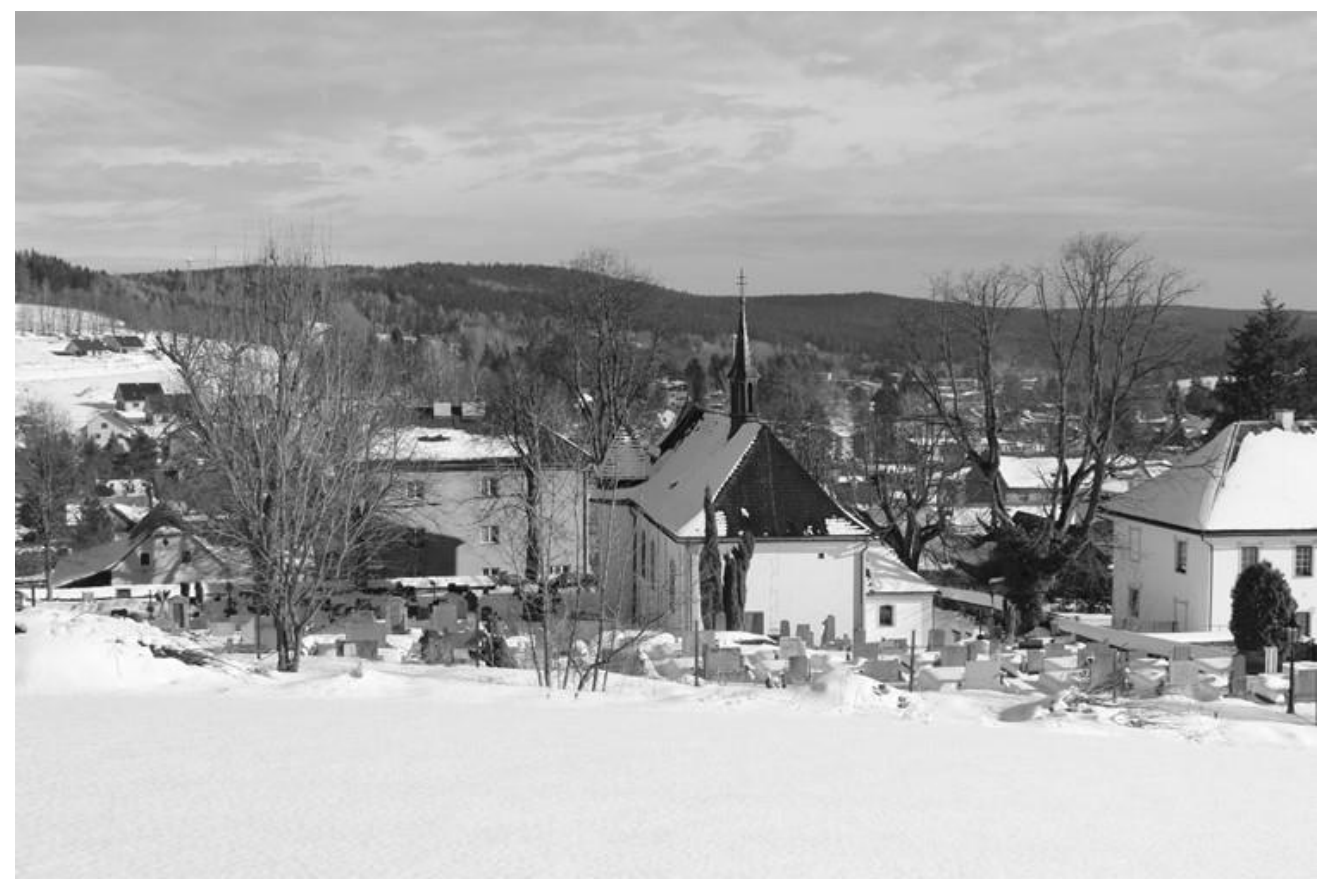


Skokanová H., Slach T., Havlíček M., Halas P., Divíšek J., Špinlerová Z., Koutecký T., Šebesta J., Kallabová E.: Landscape painting in the research of landscape changes

Table 3: Changes in the land cover depicted in the landscape paintings as observed in present, expressed by the share $(\%)$ of the number of paintings where the individual changes occurred. "++" - significant increase in the area, "+" increase in the area, "0" - no change in the area, "“- - decrease in the area, "N/A" - the land cover category is not present in the painting

\begin{tabular}{lccccc}
\hline rating scale & arable land & grassland & woody vegetation & built-up & water body \\
& & & & & \\
\hline++ & 0 & 0 & 4 & 7 & 1 \\
\hline+ & 4 & 29 & 88 & 41 & 4 \\
\hline 0 & 23 & 18 & 8 & 32 & 89 \\
\hline- & 63 & 53 & 1 & 4 & 47 \\
\hline N/A & 10 & 1 & 0 & 15 & \\
\hline
\end{tabular}

Land cover categories representing agricultural use, i.e. arable land and grassland, experienced decrease of their area. Arable land was reduced in $63 \%$ of the landscape paintings, mainly from group (C) but to a lesser degree also from the other two groups. It remained approximately the same in $23 \%$ of the paintings but increased in $4 \%$ of the paintings. There are $10 \%$ of the paintings where arable land did not occur at all. Grassland decreased in $53 \%$ of the landscape paintings, mostly from group (A) and remained unchanged in $18 \%$, predominantly in group (C). However, unlike arable land, $29 \%$ of the landscape paintings, especially from group (C) showed an increase in the area of this category.

Regarding specific land cover type - water bodies, there were not as dramatic changes as in the previous cases. It might be caused by the fact that water bodies were rather scarce - they did not occur in $47 \%$ of the landscape paintings. In $39 \%$, their area remained the same. An increase was recorded for $5 \%$ (one case recorded a significant increase as it was a result of building a water reservoir) and was typical for paintings from group (C) and decrease for $8 \%$, typical for paintings from group (A).

Changes captured by time series of land cover development in the cadastres where the landscape paintings and their directions were localised confirmed general trends of increase in the area of forest/woody vegetation and built-up areas but the decrease of agricultural land (Table 4). Despite this fact, agricultural land has dominated until present in cadastres with landscape paintings from group (A) (paintings from 1728-1850) and group (B) (paintings from 1864-1930). Only cadastres with landscape painting from group (C) (paintings from 1931-1976) were covered more by forests than open landscape. 
Table 4: Land cover development (expressed by proportion of area) for landscape paintings from period 1728-1850 (A), 1864-1930 (B) and 1931-1976 (C)

\begin{tabular}{|c|c|c|c|c|c|}
\hline \multicolumn{6}{|l|}{$\mathbf{A}$} \\
\hline land cover & 1840s & 1870s & 1950s & $1990 \mathrm{~s}$ & $2000 s$ \\
\hline other area & 0,0 & 0,0 & 0,1 & 0,4 & 0,3 \\
\hline arable land & 49,6 & 53,8 & 49,0 & 41,5 & 37,0 \\
\hline permanent grassland & 17,9 & 11,0 & 7,7 & 5,5 & 8,5 \\
\hline orchard & 0,3 & 0,5 & 1,6 & 1,1 & 1,2 \\
\hline vineyard & 0,9 & 0,7 & 0,5 & 0,7 & 0,7 \\
\hline forest & 27,2 & 30,2 & 32,2 & 33,7 & 34,0 \\
\hline water body & 0,8 & 0,2 & 0,9 & 0,9 & 0,9 \\
\hline built-up area & 3,1 & 3,6 & 7,9 & 13,8 & 14,7 \\
\hline recreational area & 0,0 & 0,0 & 0,1 & 2,4 & 2,6 \\
\hline \multicolumn{6}{|l|}{ B } \\
\hline land cover & & 1870s & 1950s & $1990 \mathrm{~s}$ & $2000 s$ \\
\hline other area & & 0,0 & 0,1 & 0,1 & 0,1 \\
\hline arable land & & 52,2 & 47,7 & 41,0 & 39,2 \\
\hline permanent grassland & & 13,7 & 9,5 & 9,4 & 10,3 \\
\hline orchard & & 0,3 & 0,7 & 0,4 & 0,2 \\
\hline vineyard & & 0,3 & 0,0 & 0,0 & 0,0 \\
\hline forest & & 29,9 & 32,1 & 33,8 & 34,4 \\
\hline water body & & 0,2 & 0,2 & 0,6 & 0,5 \\
\hline built-up area & & 3,4 & 9,7 & 13,8 & 14,4 \\
\hline recreational area & & 0,0 & 0,1 & 0,9 & 0,9 \\
\hline \multicolumn{6}{|l|}{$\mathbf{C}$} \\
\hline land cover & & & 1950s & $1990 \mathrm{~s}$ & $2000 s$ \\
\hline other area & & & 0,0 & 0,0 & 0,0 \\
\hline arable land & & & 31,3 & 23,8 & 19,9 \\
\hline permanent grassland & & & 9,5 & 10,7 & 13,6 \\
\hline orchard & & & 0,1 & 0,3 & 0,2 \\
\hline forest & & & 55,9 & 59,2 & 59,9 \\
\hline water body & & & 0,2 & 1,1 & 1,1 \\
\hline built-up area & & & 2,8 & 4,3 & 4,5 \\
\hline recreational area & & & 0,1 & 0,5 & 0,7 \\
\hline
\end{tabular}


Skokanová H., Slach T., Havlíček M., Halas P., Divíšek J., Špinlerová Z., Koutecký T., Šebesta J., Kallabová E.:

Landscape painting in the research of landscape changes

Table 5: Rate of change $(\%)$ in a 10-year trend in the area of land cover categories for landscape paintings from period 1728-1850 (A), 1864-1930 (B) and 1931-1976 (C); N/A - category did not occur in the given period

\begin{tabular}{|c|c|c|c|c|}
\hline \multicolumn{5}{|l|}{ A } \\
\hline land cover & $1840 \mathrm{~s}-1870 \mathrm{~s}$ & $1870 \mathrm{~s}-1950 \mathrm{~s}$ & $1950 \mathrm{~s}-1990 \mathrm{~s}$ & $1990 \mathrm{~s}-2000 \mathrm{~s}$ \\
\hline other area & 0,0 & 0,0 & 0,1 & 0,0 \\
\hline arable land & 1,0 & $-0,6$ & $-1,9$ & $-4,1$ \\
\hline permanent grassland & $-1,7$ & $-0,4$ & $-0,6$ & 2,8 \\
\hline orchard & 0,0 & 0,1 & $-0,1$ & 0,1 \\
\hline vineyard & $-0,1$ & 0,0 & 0,0 & 0,0 \\
\hline forest & 0,7 & 0,2 & 0,4 & 0,3 \\
\hline water body & $-0,2$ & 0,1 & 0,0 & 0,0 \\
\hline built-up area & 0,1 & 0,5 & 1,5 & 0,8 \\
\hline recreational area & N/A & 0,0 & 0,6 & 0,1 \\
\hline \multicolumn{5}{|c|}{ B } \\
\hline land cover & & $1870 s-1950 s$ & 1950s-1990s & $1990 \mathrm{~s}-2000 \mathrm{~s}$ \\
\hline other area & & 0,0 & 0,0 & 0,0 \\
\hline arable land & & $-0,6$ & $-1,7$ & $-1,6$ \\
\hline permanent grassland & & $-0,5$ & 0,0 & 0,8 \\
\hline orchard & & 0,0 & $-0,1$ & $-0,2$ \\
\hline vineyard & & 0,0 & 0,0 & 0,0 \\
\hline forest & & 0,3 & 0,4 & 0,5 \\
\hline water body & & 0,0 & 0,1 & $-0,1$ \\
\hline built-up area & & 0,8 & 1,1 & 0,6 \\
\hline recreational area & & 0,0 & 0,2 & 0,0 \\
\hline \multicolumn{5}{|c|}{$\mathbf{C}$} \\
\hline land cover & & & 1950s-1990s & 1990s-2000s \\
\hline other area & & & 0,0 & 0,0 \\
\hline arable land & & & $-1,9$ & $-3,6$ \\
\hline permanent grassland & & & 0,3 & 2,6 \\
\hline orchard & & & 0,0 & 0,0 \\
\hline forest & & & 0,8 & 0,6 \\
\hline water body & & & 0,2 & 0,0 \\
\hline built-up area & & & 0,4 & 0,2 \\
\hline recreational area & & & 0,1 & 0,1 \\
\hline
\end{tabular}


Comparing two adjacent periods revealed where the highest rate of change occurred. Regarding forest/woody vegetation, the highest rate of increase in its area was identified in a group (A) for the end of the $19^{\text {th }}$ century. Forests in this period spread predominantly on grassland. In a group (B), the highest increase in forest/woody vegetation per 10 years occurred at the turn of the $21^{\text {st }}$ century, and in a group (C), it was between 1950s and 1990s. In both periods and groups, the forest spread mainly on arable land. The highest increase in built-up area was documented in the second half of the $20^{\text {th }}$ century regardless the time of the painting's origin (Table 5). New built-up areas occurred predominantly on arable land.

All groups experienced the highest increase rate in grassland at the turn of $21^{\text {st }}$ century by grassing former arable fields. Decrease of grassland was typical only for paintings from groups (A) and (B) and the highest rate of decrease was recorded between the first two periods of their respective time span - for group (A), it was between 1840s and 1870s, for group (B), it was between 1870s and 1950s. In both cases, grassland was mainly turned into arable land, although afforestation also played a significant role for group (A). Groups (A) and (C) experienced the highest decrease of arable land at the turn of the $21^{\text {st }}$ century when it was turned to grassland. In a group (B), the highest decrease of arable land occurred during the second half of the $20^{\text {th }}$ century and was caused mainly by the spread of built-up areas. Interestingly, the decrease rate of this category during the second half of the $20^{\text {th }}$ century was similar in all three groups and was around $2 \%$ per 10 years.

\section{DISSCUSSION}

\section{Comparison of paintings with maps from corresponding period}

Our results show that landscape paintings, especially realistic ones, can show an accurate portrait of the landscape in the time when the painting was acquired. The comparison with the topographic maps confirmed this presumption regarding general features of the landscape. Therefore, they could supplement topographic maps in periods where the cartographic sources are missing.

Landscape paintings are usually more detailed than topographic maps, even of large scale, such as stable cadastre from the $19^{\text {th }}$ century. This is due to the purpose of the map and therefore its content and due to the scale in which the map is drawn, which necessarily leads to a considerable generalisation. On the other hand, although paintings are mostly more detailed and filled with information, they display more or less narrow sector of the landscape, only a fragment. Therefore, landscape paintings might be very well used for capturing some main trends but they are not appropriate for precise statistical analysis, especially for large areas. Landscape paintings, like topographic maps, represent a spatially discontinuous fragmented source of information. This needs to be taken into account when using them.

The main benefit of using landscape paintings in the landscape studies consists in the documentation of the scene directly by the author as an insider of such a specific location. The maps to a certain extent generalize the captured landscape while the paintings convey the real image of the location with other aspects and specifics. For example, landscape structures determined by vegetation formation and biomass cannot be mostly deduced by maps but paintings can reveal such information. Another example can be seen in capturing certain habitat type, which has been lost, such as a steppe grassland, or even species composition in today's overgrown areas.

Our article did not focus on comparing landscape paintings with aerial photographs. Such comparison might reveal even better accuracy of the painted landscape. The main drawback of using aerial photographs for such exercise is the fact that the earliest photos are from the 1930s (Pacina \& Popelka, 2017) and therefore paintings from earlier periods cannot be part 
Skokanová H., Slach T., Havlíček M., Halas P., Divíšek J., Špinlerová Z., Koutecký T., Šebesta J., Kallabová E.: Landscape painting in the research of landscape changes

of such analyses. Furthermore, distinguishing between land use categories, especially arable fields and grasslands, on black and white photographs can be quite difficult.

Accuracy and suitability of the landscape painting also depend on the particular painter and his/her style connected with the sense of balancing between precise depicting of reality and aesthetics, resulting mostly in generalisation. Moreover, it was shown that some painters omitted some features from the landscape they depicted because they were not "aesthetically pleasing". Josef Jambor, a famous Czech landscape painter of the $20^{\text {th }}$ century, can serve as an example. As his work is brilliant for assessing landscape changes because of its enormous precision and fullness of details, it is necessary to stay cautious while using it. He has been well known for his admiration of the glamor of a traditional rural landscape. Therefore, in the painting Loučky u Tišnova (1960) showing a panorama of the village of the same name, Jambor omitted displaying big railway viaduct, although it probably existed for more than ten years before the painting was created. For him, technical advantages were considered as something negative inhibiting traditional values and the face of the landscape. Other authors were known to e.g. exaggerate the height of the horizon or reduce other aspects, e.g. Czech painter Julius Mařák who dramatized and idealised some objects in selected Bohemian and Moravian localities (Lacina \& Halas, 2015). Therefore, it should be stressed that using landscape paintings in the studies of landscape represent more qualitative, rather than quantitative approach. One should be also aware of their limits regarding their accuracy due to painter's style.

\section{Land cover development}

Land cover development trends captured by landscape paintings and in their surroundings analysed with the help of both "TopoLandUse" database and field survey correspond with general land cover trends that occurred elsewhere in the Czech Republic. These trends include the intensification of agriculture at the end of $19^{\text {th }}$ century, high urbanisation in the second half of the $20^{\text {th }}$ century, agricultural extensification (grassing) at the beginning of the $21^{\text {st }}$ century and agricultural land abandonment connected mainly with afforestation throughout the whole study period (Skokanova et al., 2016; Bičík et al., 2015).

Intensification of agriculture was manifested mainly by the increase in the area of arable land at the detriment of permanent grassland, which is typical especially in the lower elevations (Havlicek et al., 2014; Kilianova et al., 2017). It can be seen in the paintings from group (A). On the other hand, intensification of agriculture was in several cases from group (A) combined with afforestation at the same time. This was caused mainly by afforesting less productive soils (Bičík et al., 2001) that were associated with cadastres from higher elevations. These findings correspond with other studies from the Czech Republic and Slovakia (Oprsal et al., 2013; Sul'ovsky et al., 2017). Afforestation as the result of agricultural land abandonment occurring in the second half of the $20^{\text {th }}$ century in groups (B) and $(\mathrm{C})$ can be attributed to economic reasons, namely profitability of expensive inputs in the form of fertilisers and pesticide-related to the most productive soils (Kohlheb \& Krausmann, 2009). The spread of woody vegetation in the present landscape is a consequence not only of economic reasons but also of depopulation in the form of migration to cities (Petrovič, 2006; Petrovič \& Petrikovičová, 2021).

The second half of the $20^{\text {th }}$ century was affected not only by afforestation of less fertile soils but also by spread of built-up areas. This applies especially to groups (A) and (B), i.e. localities in lower to middle elevations where the majority of existing settlements were situated. The spread of built-up areas in these localities can be associated with the spread of non-agricultural activities such as construction of residential housing, industrial plants or 
agricultural buildings (Skokanova et al., 2016) but also the spread of recreational areas, typical for more natural, mainly mountain, areas (Janík et al., 2019).

Finally, the massive spread of grassland, which started at the beginning of the $21^{\text {st }}$ century and to some extent continues till present is a result of political and cultural driving forces, namely subsidies connected with agri-environmental schemes and landscape protection programmes (Skokanova et al., 2016). These subsidies are targeted mainly for economically less favourable regions (Havlicek et al., 2018a) or for the protection of valuable landscape elements (Havlicek et al., 2018b). It should be pointed out that such grassing does not necessarily mean higher plant diversity since the grassing mixes often include only several types of plants (Jongepierová \& Malenovský, 2012), typically common grasses and legumes (Prach et al. 2014). Therefore, many valuable species were lost during ploughing grasslands in previous periods.

\section{CONSLUSiON}

Realistic landscape paintings indeed can be a valuable source for analysing land cover changes, especially in periods with lack of other, namely spatial data in the form of topographic maps and other cartographic sources but also non-cartographic sources, such as photographs. This fact was confirmed by our analyses, which revealed that more than $70 \%$ of assessed paintings were in concordance with topographic maps from respective period. As additional bonus, landscape painting can provide details that topographic maps lack. However, we should be aware of the fact the reliability of the paintings depends on the painter and that they capture only a narrow part of the landscape. This means that landscape paintings should be considered as a provider of qualitative data. However, they still can be seen as a valuable source depicting major landscape changes. It is also important to localise as precisely as possible the place from which the painting was done in order to get the most accurate overview of the changes the landscape experienced.

Here analysed landscape paintings revealed the true appearance of past landscapes and trends in specifics of past periods as the intensification of agriculture (end of $19^{\text {th }}$ century) and high urbanisation (1950-2000). The selection of analysed paintings captured all present-day main trends in land cover change as the spread of woody vegetation, agricultural extensification and abandonment of rural land. Furthermore, comparison of old and new images confirmed the spread of grasslands and the slow abandonment of landscape in higher elevations, which can be seen not only in the Czech Republic but also in other parts of Europe.

\section{AKNOWLEDGMENT}

The article was supported by Technological Agency of the Czech Republic and is an output of project TL02000222 Promoting tourism by entering to the landscape paintings and photographs.

\section{CONFLICTS OF INTEREST}

The authors declare no conflict of interest. 
Skokanová H., Slach T., Havlíček M., Halas P., Divíšek J., Špinlerová Z., Koutecký T., Šebesta J., Kallabová E.: Landscape painting in the research of landscape changes

\section{REFERENCES}

Allanson, P., Moxey, A., (1996). Agricultural land use change in England and Wales, 1892-1992. Journal of Environmental Planning and Management, 39, 243-254.

Bao, J.L., Gao, S., Ge, J.X., (2019). Dynamic land use and its policy in response to environmental and social-economic changes in China: A case study of the Jiangsu coast (1750-2015). Land Use Policy, 82, 169-180.

Barasa, B., Egeru, A., Okello, P., Mutuzo, F., (2010). Dynamics of land use/cover trends in Kanungu District, South-western Uganda. Journal of Applied Sciences and Environmental Management, 14, 67-70.

Bender, O., Boehmer, H.J., Jens, D., Schumacher, K., (2005). Analysis of land-use change in a sector of Upper Franconia (Bavaria, Germany) since 1850 using land register records. Landscape Ecology, 20, 149-163.

Bičík, I., Jeleček, L., Štěpánek, V., (2001). Land-use changes and their social driving forces in Czechia in the 19th and 20th centuries. Land Use Policy, 18, 65-73.

Bičík, I., Kupková, L., Jeleček, L., Kabrda, J., Štych, P., Janoušek, Z., Winklerová, J., (2015). Land Use Changes in the Czech Republic 1845-2010. Springer, Cham.

Boon, P., (2017). The Hawkesbury River: A Social and Natural History. Csiro Publishing, Clayton South.

Brown, M., Byrne, P., Forbes, S., (2002). Whispering of the Wannon: an oral and ecological history of the Wannon River in South West Victoria. Glenelg Hopkins Catchment Management Authority.

de Nuelenaere, S., Frankl, A., Haile, M., Poesen, J., Deckers, J., Munro, S., Veraverbeke, S., Nyssen, J., (2012). Historical landscape photographs for calibration of Landsat land use/cover in the northern Ethiopian highlands. Land Degradation and Development, 25, 319-335.

Devrani, R., Singh, V., (2012). Determining the geomorphic changes in Srinagar (Garhwal) valley, NW Himalaya in last two centuries using landscape painting. Zeitschrift für Geomorphologie Supplementary Issues, 58, 163-173.

Fonji, S., Taff, G., (2014). Using satellite data to monitor land-use land-cover change in North-eastern Latvia. SpringerPlus, 3, 1-15.

Frajer, J., Simacek, P., (2019). Localisation of the painter's canvas: landscape paintings from the Iron Mountains (Czech Republic). Journal of Maps, 15, 66-74.

Fraser, L., (2017). The Barbizon school (1830-1870): Expanding the landscape of the modern art market. The Arbutus review 8, DOI: 10.18357/tar81201716809.

Gaynor, A., McLean, I, (2008). Landscape Histories: Mapping Environmental and Ecological Change Through the Landscape Art of the Swan River Region of Western Australia. Environment and History, 14, 187-204.

Guse, B., Pfannerstill, M., Fohrer, N., (2015). Dynamic Modelling of Land Use Change Impacts on Nitrate Loads in Rivers. Environmental Processes-an International Journal, 2, 575-592.

Havlicek, M., Pavelkova, R., Frajer, J., Skokanova, H., (2014). The long-term development of water bodies in the context of land use: the case of the Kyjovka and Trkmanka river basins (Czech Republic). Moravian Geographical Reports, 22, 39-50. 
Havlicek, M., Skokanova, H., Dostal, I., Vymazalova, M., Pavelkova, R., Petrovic, F., (2018a). The consequences of establishing military training areas for land use development-A case study of Libava, Czech Republic. Land Use Policy, 73, 84-94.

Havlicek, M., Skokanova, H., Sarapatka, B., Netopil, P., Pavelkova, R., (2018b). Development of land use of the Kyjovská pahorkatina hilly land, discussion of valuable historical landscape structures, their protection, management and potential for restoration. Geograficke Informacie, 22, 103-117.

Havlíček, M., Slach, T., Skokanová, H., Halas, P., Kallabová, E., Koutecký, T., Šebesta, J., (2021). Resuscitation of landscape painting by research of landscape changes. In: Fialová, J. (Ed.), Public Recreation and Landscape Protection - With Sense Hand in Hand! (pp. 410-414), Conference Proceedings.

Hirst, R.A., Pywell, R.F., Putwain, P.D., (2000). Assessing habitat disturbance using an historical perspective: The case of Salisbury Plain military training area. Journal of Environmental Management, 60, 181-193.

Hu, S.S., Fan, Y.Y., Zhang, T., (2020). Assessing the Effect of Land Use Change on Surface Runoff in a Rapidly Urbanized City: A Case Study of the Central Area of Beijing. Land, 9. DOI: 10.3390/land9010017.

Janík, T., Zýka, V., Skokanová, H., Borovec, R., Demková, K., Havlíček, M., Chumanová, E., Houška, J., Romportl, D., (2019). Landscape development on the territory of the NP and PLA Šumava since the 1950s till present. Silva Gabreta, 25, 1-14.

Jongepierová, I., Malenovský, I., (2012). Grasslands. Introduction. In: Jongepierová, I., Pešout, P., Jongepier, J.W., Prach, K. (eds), Ecological restoration in the Czech Republic, 35-38.

Jung, M., Scharlemann, J.P.W., Rowhani, P., (2020). Landscape-wide changes in land use and land cover correlate with, but rarely explain local biodiversity change. Landscape Ecology, 35, 2255-2273.

Kienast, F., (1993). Analysis of historic landscape patterns with a Geographical Information System - a methodological outline. Landscape Ecology, 8, 103-118.

Kilianova, H., Pechanec, V., Brus, J., Kirchner, K., Machar, I., (2017). Analysis of the development of land use in the Morava River floodplain, with special emphasis on the landscape matrix. Moravian Geographical Reports, 25, 46-59.

Kohlheb, N., Krausmann, F., (2009). Land use change, biomass production and HANPP: The case of Hungary 1961-2005. Ecological Economics, 69, 292-300.

Konkoly-Gyuró, É., Király, G., Nagy, D., Balázs, P., Tirászi, Á., (2017). Overview of the $18^{\text {th }}-20^{\text {th }}$ century military surveys in the light of the land cover change assessment in Eastern Central Europe. e-Perimetron, 12, 142-180.

Lacina, J., Halas, P., (2015). Landscape Painting in Evaluation of Changes in Landscape. Journal of Landscape Ecology (Czech Republic), 8, 60-68.

Landing, C.E.., (2020). National romanticism and the Swedish landscape. Swedish art of the 1980s. MPhil thesis, University of Glasgow.

Lieskovský, J., Kanka, R., Bezák, P., Štefunková, D., Petrovič, F., Dobrovodská, M., (2013). Driving forces behind vineyard abandonment in Slovakia following the move to a market-oriented economy. Land Use Policy, 32, 356-365. 
Liu, M., Hu, Y.M., Zhang, W., Zhu, J.J., Chen, H.W., Xi, F.M., (2011). Application of land-use change model in guiding regional planning: A case study in Hun-Taizi River Watershed, Northeast China. Chinese Geographical Science, 21, 609-618.

Oprsal, Z., Sarapatka, B., Kladivo, P., (2013). Land-use changes and their relationships to selected landscape parameters in three cadastral areas in Moravia (Czech Republic). Moravian Geographical Reports, 21, 41-50.

Pacina, J., Popelka, J., (2017). Accuracy of Digital Surface Models derived from archival aerial photographs. Case study for the Czech Republic. Geoinformatics FCE CTU 16, 53-62.

Petek, F., (2002). Methodology of evaluation of changes in land use in Slovenia between 1986 and 1999. Geografski zbornik, XLII, 61-88.

Petrovič, F., (2006). Changes of the landscape with dispersed settlement. Ekologia Bratislava, 25, 201-211.

Petrovič, F., Petrikovičová, L., (2021). Landscape Tranformation of Small Rural Settlements with Dispersed Type of Settlement in Slovakia. European Countryside, 13, 455-478.

Piana, P., Watkins, Ch., Balzaretti, R., (2021). Rediscovering Lost Landscapes. Topographical Art in north-west Italy, 1800-1920. Boydell \& Brewer Ltd.

Popovici, E.A., Kucsicsa, G., Balteanu, D., Grigorescu, I., Mitrica, B., Dumitrascu, M., Damian, N., (2018). Past and future land use/land cover flows related to agricultural lands in Romania. An assessment using Clue-S model and Corine Land Cover database. Carpathian Journal of Earth and Environmental Sciences, 13, 613-628.

Prach, K., Jongepierová, I., Řehounková, K., Fajmon, K., (2014). Restoration of grasslands on ex-arable land using regional and commercial seed mixtures and spontaneous successsion: Successional trajectories and changes in species richness. Agriculture, Ecosystems \& Environment, 182, 131-136

Rees, R., (1973). Geography and landscape painting: An introduction to a neglected field. Scottish Geographical Magazine, 89, 147-157.

Rounsevell, M.D.A., Reay, D.S., (2009). Land use and climate change in the UK. Land Use Policy, 26, S160-S169.

Skanes, H.M., Bunce, R.G.H., (1997). Directions of landscape change (1741-1993) in Virestad, Sweden - characterised by multivariate analysis. Landscape and Urban Planning, $38,61-75$.

Skokanova, H., Faltan, V., Havlicek, M., (2016). Driving forces of main landscape change processes from past 200 years in Central Europe: Differences between old democratic and post-socialist countries. Ekologia (Bratislava), 35, 50-65.

Skokanova, H., Havlicek, M., Borovec, R., Demek, J., Eremiasova, R., Chrudina, Z., Mackovcin, P., Ryskova, R., Slavik, P., Stranska, T., Svoboda, J., (2012). Development of land use and main land use change processes in the period 1836-2006: case study in the Czech Republic. Journal of Maps, 8, 88-96.

Skokanova, H., Netopil, P., Havlicek, M., Sarapatka, B., (2020). The role of traditional agricultural landscape structures in changes to green infrastructure connectivity. Agriculture Ecosystems \& Environment, 302.

Sul'ovsky, M., Faltan, V., Skokanova, H., Havlicek, M., Petrovic, F., (2017). Spatial analysis of long-term land-use development in regard to physiotopes: case studies from the Carpathians. Physical Geography, 38, 470-488. 
Yang, J., Yan, P.B., He, R.X., Song, X.Q., (2017). Exploring land-use legacy effects on taxonomic and functional diversity of woody plants in a rapidly urbanizing landscape. Landscape and Urban Planning, 162, 92-103.

Zebisch, M., Wechsung, F., Kenneweg, H., (2004). Landscape response functions for biodiversity--assessing the impact of land-use changes at the county level. Landscape and Urban Planning, 67, 157-172. 